\title{
A structural model of creative industry for small medium enterprise innovation indexes
}

\author{
L Zafriana ${ }^{1}$, AH Nasution ${ }^{2 *}$ \\ ${ }^{1}$ Department of Industrial Engineering, Kartini University, Surabaya, Indonesia \\ ${ }^{2}$ Department of Busines Management, Institut Teknologi Sepuluh Nopember, Kampus \\ ITS, Sukolilo, Surabaya-60111, Indonesia \\ *armanhakim.nasution@gmail.com
}

\begin{abstract}
Problems on Indonesia Small-Medium Enterprise (SME) are identified in the financial area, organization and management, network and export capabilities. There are numerous cases suggesting that SME problem lies in the competitiveness area, related with their innovation capabilities. Reducing its weakness, it is needed to build SME innovation indexes by using Structural Equation Modelling (SEM). This model is composed of 4 (four) construct variables, its technology, marketing/information, product quality, and organization management. All of variables will compose values of sub indexes dan efficiency market that determine the final value of SME innovation indexes in different criteria. The application of structural model on SME innovation indexes by using simulation data conclude that technology and marketing/information variables have impact on strategy sub indexes as 5,3\%. Quality product and management/organization variables have impact as $149,8 \%$ on market efficiency. By using normalization value, the biggest role as $96 \%$ is determined by product quality and management organization, the rest of $4 \%$ come from technology and market/information. Sub indexes variable and market efficiency have impact on SME Innovation Indexes as 49,4\%.
\end{abstract}

Keywords: creative industry; innovation indexes; structural equation modelling

\section{Introduction}

Small-Medium Enterprise (SME) is labeled to those sectors existing in-between micro/large business with varied definitions by different institutions/countries. Those definitions are basically based on size of workforce, revenue and assets. Such varied definitions result in rather weak regulations and support for SME which in turn produce somewhat incomprehensive, unfocused and overlapping policies (1). Furthermore, it will bring about implications as to whom fund is allocated, how much of it a business unit can be granted as it is decided by each government body instead of a wellcoordinated government economy, not allowing the effort to upgrade SME (SME upgrading program) to be efficient. Urata pointed out several problems faced by SME in Indonesia (1), i.e.: finance, organization management, network and capability to export

The unsynchronized availability of liquidity made accessable to SME, an absence of a systematic approach, high transaction cost due to complicated credit application procedures, high interest of capital and investment credit, a high number of unbankable SME are among the finance problems.

Among the organization management (non-financial) problems are limited knowledge on technology and production quality due to low education and training, limited information on the market, weak human resource and limited development and innovation ability, and unawareness of the 
importance of financing and accounting. Limitation on human resource as an integrated part of SME weakness is one of the "structural" challenges faced by SME in Indonesia as $70 \%$ of the workforce is elementary school graduate who do not receive secondary education because of poverty. Other problems are related to export, i.e.: scarce information on export opportunities, an insufficient number of institutions to assist in developing export, time and energy-consuming paperwork and licensing as well as sources of liquidity to export.

\section{Literatur Review}

\subsection{Creative Industry SME and Its Potentials}

Creative industry is defined as an industrial sector which accommodates individual creativity, skill and talent, which has the potential to create welfare and jobs by creating and exploiting intellectual property (2).

In advanced economies such as the USA, Australia, Singapore and the European countries, creative industry is constantly being developed and optimized to drive the national economy. The global creative industry has contributed US\$2 Billions to the global Gross Domestic Product (GDP) and within two years it will account for US\$10 Billions.

According to the Minister of Commerce, Mari Elka Pangestu, Indonesian creative industry contributes a mere $1.9 \%$ to the GDP. However, it is targeted to achieve a $10 \%$ within $5-8$ years. The Ministry of Commerce registered 15 sectors in creative industry, i.e.: advertisement, art, design, film, performance art, research and development, television and radio, video game, architecture, handicraft, fashion, music, publishing, software and games.

Speaking about SME innovation indexes, it is only appropriate to have one which is capable of measuring the competence of creative industry-based SME. By definition, the creative industry is innovative in nature as it explores intellectual property which is based on creativity, culture and innovation to increase business productivity and performance.

Creative industry, according to Tan (3). simply put, is a merger of three economic pillars, i.e.: Knowledge Based Economic (KBE), Resources Based Economic (RBE), and Culture Based Economic (CBE). In addition, creative industry is high in intelligence while it is low in capital and workforce, making it proper to asses the innovation index of upgradeable SME.

\subsection{Innovation and Competitiveness of SME}

The importance of innovation does not apply only to business organization. Several developed countries see its importance by establishing a department or a unit to take the responsibility of the development of innovation in order to improve competitiveness (4).

The USA which is ranked at 4th place for overall performance in the Global Competitiveness Indexes (GCI) and ranked also at 4th place for the sub-index innovation (WEF report 2010) has run an innovation department since 2008. Britain as a developed country in Europe, ranked at 12th place in both overall GCI 2010 and for sub index innovation, has initiated to build links to connect innovation and job opportunities, financial benefit and living standard (4). In developing countries such as Chezh, a national program to apply innovation research and development (R\&D) between universities and SME has been conducted since 2001 with the pilot project Leonardo da Vinci U-SME program (5).

Regarding the relation of innovation and SME sector, comparing it to bureaucratic large enterprises, SME excels in the product development technology innovation and the flexibility to adjust with the market which changes rapidly (6). SME is more flexible in product innovation and marketing innovation.

\section{Research Method}

\subsection{Theoritical Model of Innovation Competitiveness}

Some innovation theoretical models relevant to SME innovation index research are the CGI model as a macro model of national competitiveness and European Innovation Standard (EIS) model serving as a more micro model. Eventhough there are other models such as R\&D or Value Added Scoreboards, 
Creativity Index and Taiwan/Hawaai Innovation Index, this paper will only present GCI dan EIS model as they are considered to represent the framework by which a desired model will be constructed.

\subsection{Global competitiveness Indexes (GCI) Model}

One world organization to regularly analyse the global competitiveness of world nations with Global Competitiveness Index (CGI) is World Economic Forum (WEF). GCI is not the competitiveness index of individual export product as with Trade Performance Index (TPI) but rather the competitiveness index of an economy/individual country. Thus, GCI serves well not only to examine export competitiveness of a country but also its competitiveness to attract foreign investment.

There are three groups of factors to decide the competitiveness of a country in the GCI model (7). First, basic requirements such as institutionalization, infrastructure, macro economy, education and public health. They are regarded as the main drive of economic process/growth. Empirically, they are proven to have positive impact on economic growth. The second group of factors is those which enhance efficiency (or productivity) such as high education and training (human resource quality), efficient market performance and technology advancement at the national level as well as the individual enterprise. The third group of factors is innovation and production process advancement within companies which simultaneously determine the innovation level of a country.

\subsection{European Innovation Scoreboard (EIS) Model}

EIS, according to (8), base its measurement on 29 sub-indicators of measurement, classified into 7 (seven) categories of innovation trigger, i.e.: human resources (5 sub-indicators of measurement), finance and its support (4 sub-indicators of measurement), company investment ( 3 sub-indicators of measurement), entrepeneurship (4 sub-indicators of measurement), throughput (4 sub-indicators of measurement), innovation ( 3 sub-indicators of measurement) and economic effect (6 sub-indicators of measurement).

Contrary to GCI model which utilizes macro indicator of measurement, EIS bases its measurement by utilizing indicators which are more of micro "middle". For instance, when high educated human resource in the Efficiency Enhancer sub-factor of GCI model is measured by 8 (eight) assessment indicators which are process in nature, or "have indirect impacts", i.e.: quality of education system, school management, quality of mathematics and science education, access to the internet, etc, the EIS model assessment indicators seek to measure the end throughput of the processes supported by wellconducted "efficiency enhancer" as described in GCI model measures.

\subsection{Proposed Model of SME Innovation Index}

An SME Innovation Index Model as an innovation index which is somewhat micro in nature has to be constructed in such a way to enable it to serve as a sub-contributor to the enhancement of GCI innovation index which is macro in nature. Using that particular index model, the objective of "SME upgrading" program can be materialized, and the same time, contributes at the macro level to the innovation sub-index of GCI index as the key for innovation driven economic.

\subsection{Theoritical Model of SME Innovation Index}

While GCI model provides an understanding on the measurement of innovation index from the macro perspective, EIS is a model that represents measurement of innovation from a somewhat micro perspective. To allow application to SME, medium business in particular, it is in the researcher professional opinion that it calls for a model adjusted to the nature of ME in Indonesia.

Therefore, a theoritical model of SME innovation index that specifically combines a number of factors of the EIS model and synchronizes them with the sub-indexes of the GCI model, technology transfer and market efficiency sub-index in particular, is in need to be constructed.

\subsection{Conceptual Framework of the Structural Model}

The conceptual framework of the structural SMB Innovation Index Model in relation with its constituting components and its effect to the GCI sub index components is illustrated below: 


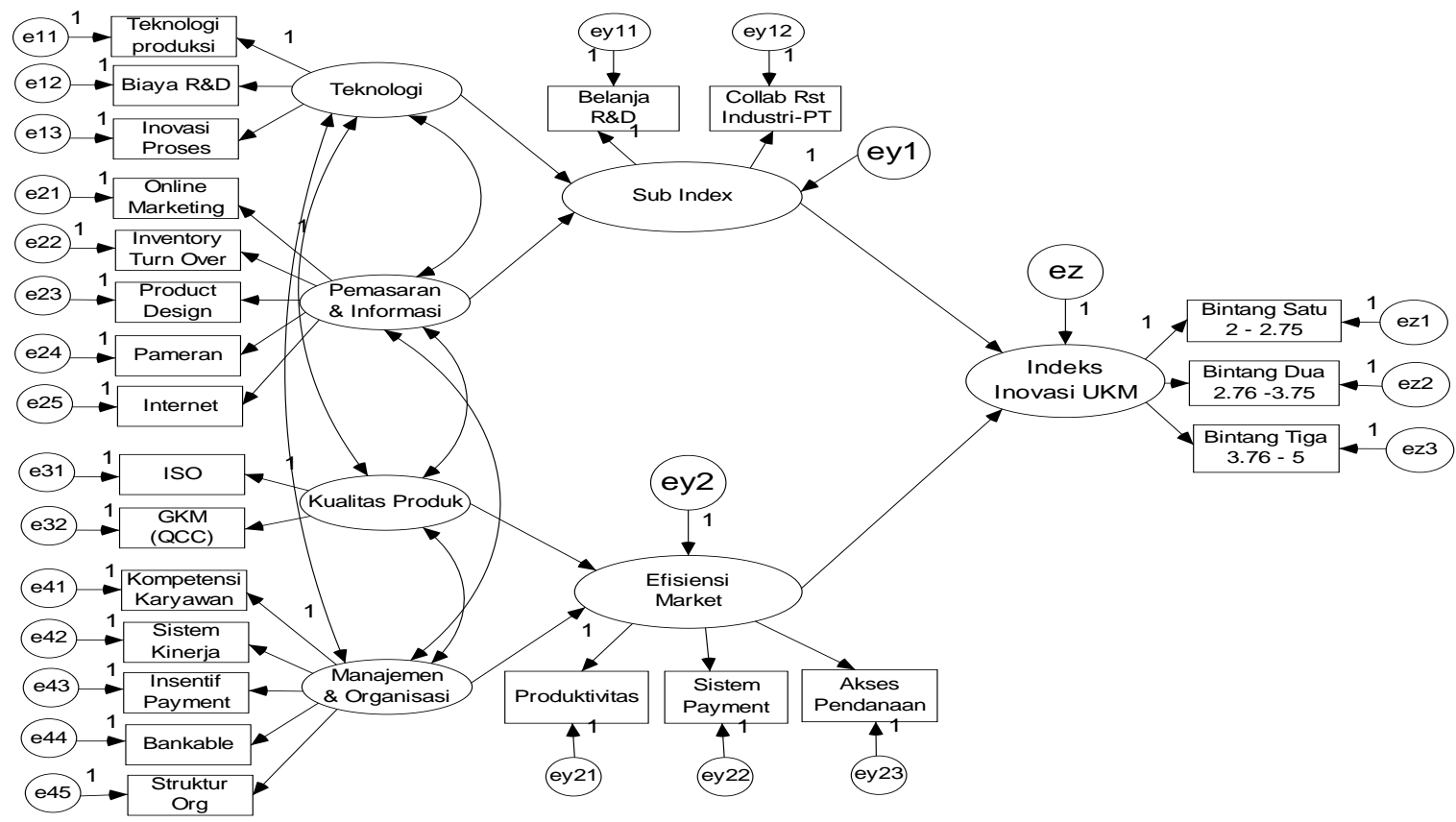

Figure 1. Theoritical framework of the structural model.

\subsection{Construct components of the model}

Four exogen variables constitute the SMB innovation index, i.e.: (1) Technology, (2) Marketing and Information, (3) Quality of product, (4) Management and Organization. The four component groups of variables directly contribute to improve 2 (two) GCI sub index components, that is the sub-indexes related to innovation, R\&D budget component and Industry-University Research Collaboration as well as market efficiency, to sub-component of productivity, payment system and access to liquidity. The four group of exogen variables that constitute the model are constructed by the construct factors illustrated in Illustration 1. Technology Group consists of 3 construct factor, Marketing and Information Group (5 sub-factors), Quality of Product Group (2 sub-factors) and Management and Organization Group (5 sub-factors). Those exogen variables contribute to construct endogen variables; that is the sub-index (Technology Transfer) which is part of the sub-indexes in the CGI model and Market Eficiency. Each construct factor is presented in Tabel 2.

\subsection{Hypothesis}

The hypothesis of this research is that there is an actual impact of technology innovation, marketing and information, product quality and management and organization in improving SME innovation index by improving the sub-indexes of technology transfer and market efficiency.

Table 1. Variables and Description.

\begin{tabular}{|c|c|c|c|c|c|}
\hline Symbol & Exogen & Measurement & Symbol & Endogen & Measurement \\
\hline $\mathrm{X} 1$ & \multirow{4}{*}{ Technology } & & \multirow{10}{*}{$\begin{array}{l}\text { Y1 } \\
\text { Y11 } \\
\text { Y12 }\end{array}$} & \multirow[t]{10}{*}{ Sub index } & \\
\hline $\mathrm{X} 11$ & & Production Technology & & & R\&D Budget \\
\hline $\mathrm{X} 12$ & & $\mathrm{R} \& \mathrm{D}$ Cost & & & $\begin{array}{l}\text { Industry-university } \\
\text { collaboration }\end{array}$ \\
\hline $\mathrm{X} 13$ & & Process innovation & & & \\
\hline $\mathrm{X} 2$ & \multirow{6}{*}{$\begin{array}{l}\text { Marketing \& } \\
\text { Information }\end{array}$} & & & & \\
\hline $\mathrm{X} 21$ & & Online marketing & & & \\
\hline $\mathrm{X} 22$ & & Inventory turn over & & & \\
\hline $\mathrm{X} 23$ & & $\begin{array}{l}\text { Product design } \\
\end{array}$ & & & \\
\hline $\mathrm{X} 24$ & & Exhibition & & & \\
\hline $\mathrm{X} 25$ & & Internet & & & \\
\hline
\end{tabular}




\begin{tabular}{|c|c|c|c|c|c|}
\hline X3 & \multirow{3}{*}{$\begin{array}{l}\text { Product } \\
\text { quality }\end{array}$} & & \multirow{9}{*}{$\begin{array}{l}\text { Y2 } \\
\text { Y21 } \\
\text { Y22 } \\
\text { Y23 }\end{array}$} & \multirow{9}{*}{$\begin{array}{l}\text { Market } \\
\text { Efficiency }\end{array}$} & \\
\hline X31 & & ISO & & & Productivity \\
\hline X32 & & $\begin{array}{l}\text { Quality Control Unit } \\
\text { (QCC) }\end{array}$ & & & Payment system \\
\hline $\mathrm{X} 4$ & \multirow{6}{*}{$\begin{array}{l}\text { Management } \\
\& \\
\text { Organization }\end{array}$} & & & & Liquidity access \\
\hline $\mathrm{X} 41$ & & Workforce competence & & & \\
\hline $\mathrm{X} 42$ & & Performance system & & & \\
\hline $\mathrm{X} 43$ & & Payment incentive & & & \\
\hline $\mathrm{X} 44$ & & Bankable & & & \\
\hline $\mathrm{X} 45$ & & Organization structure & & & \\
\hline $\mathrm{Y1}$ & \multirow{3}{*}{ Sub index } & & $\mathrm{Z}$ & \multirow{7}{*}{$\begin{array}{l}\text { SME Innovation } \\
\text { index }\end{array}$} & \\
\hline Y11 & & R\&D Budget & $\mathrm{Z} 1$ & & One star \\
\hline Y12 & & $\begin{array}{l}\text { Industry-University } \\
\text { collaboration }\end{array}$ & $\mathrm{Z} 2$ & & Two star \\
\hline Y2 & \multirow{4}{*}{$\begin{array}{l}\text { Market } \\
\text { efficiency }\end{array}$} & & $\mathrm{Z3}$ & & Three star \\
\hline Y21 & & Productivity & & & \\
\hline Y22 & & Payment system & & & \\
\hline Y23 & & Liquidity access & & & \\
\hline
\end{tabular}

\subsection{Questionnaire}

The constructing components of the model are converted into questions in a scale of 1-4 filling out likert questionnaire, circulated among SME stakeholders, which consist of 3 (three) major groups, i.e.: academics, business (practicioners of SME) and government (regulating departmenst).

\subsection{The Objective of Developing the Model}

The ultimate objective of the model is to determine an SME Innovation Index which is represented in a scale of One Star to Three Star, meaning (1) One star is an achieved scale of 2-2.75, (2) Two Star is an achieved scale of 2.76-3.75, (3) Three Star is an achieved scale of 3.76-5. The more stars it achieves, the higher the innovation level is, showing that an individual SME has indeed earned an upgrade, when which it will be rewarded with "stimuli" in terms of access to higher liquidity, expanded market and opportunities to receive stronger business support from the government.

\section{Results and Analysis}

\subsection{Model Analysis}

The model analysis will discuss the test to the model which examines whether it statistically meet the goodness of fit criteria, conduct an analysis of regression weight, direct and total effect and determinant coefficient.

\subsection{Test to the Model}

Assessing the fitness of a model is a complicated task and requires thorough attention. An index showing that a model is fit does not guarantee that it is unquestionably fit. Likewise, a fitness index concluding that a model is highly unfit does not guarantee that it is absolutely unfit. To illustrate, in the model modification stage there was an increase of $\mathrm{p}$ value, from 0.12 to 0.043 . However, since fitness requirements ask for a $\mathrm{p}$ value that is higher than or equals 0.05 , in the model modification stage, it has not met the fitness criteria.

\subsection{Model Fitness Test}

The next step is to process the data using AMOS version 16. The processed data are simulation data collected from an observation on 160 respondents. The Goodness output result of the initial model showed a p value (0.012), the GFI (Goodness of Fit Index) and the AGFI (Adjusted Goodness of Fit Index) have not met the requirements.

\subsection{Modification to the Model}


The probability value of the initial model, that is 0.012 , proved that the model was not fit. It called for a modification to enable to model to meet the requirements of the goodness of fit statistics. The first thing that must be done in executing a modification is to link the measurement error in a model in a construct based on the largest MI (Modification Indices) value. It was apparent from the initial model that the largest MI value was located at error e13 (process innovation) and error e22 (ITO) with a value of 12.878. As such, the first step of the modification was to link error e13 with error e22. The result of the process of modification concluded that the p-value, GFI, AGFI and TLI had not met the requirements, even when the value of RMSEA (Root Mean Square Error of Appoximation) and CMIN/DF (Normalized Chi Square) were good.

Modification one resulted in an increase of the p value from 0.012 to 0.043 . However, since the requirement of a fit model is a $\mathrm{p}$ value that is more than or equals 0.05 , in modification 1 the model was not fit. Modification 2 linked the measurement error e41 (employees' competence) and e45 (organization structure) as it had the largest MI value, that is 7.145. The second modification successfully created a fitted model with the p value (deviance probability between sample covariance matrix and model (fitted) covariance matrix) of 0,074.

Table 2. Result of goodness of fit statistics modification 2 (e41 \& e45).

\begin{tabular}{|c|c|c|c|}
\hline Criteria & 'Fit' Criteria & Result & Remark \\
\hline Chi-square & as less & 248,865 & Marginal \\
\hline p-value & possible & 0,074 & Good \\
\hline GFI & $\geq 0,05$ & 0,893 & Good \\
\hline AGFI & $\geq 0,9$ & 0,864 & Good \\
\hline RMSEA & $\geq 0,9$ & 0,030 & Good \\
\hline CMIN/DF & $\leq 0,08$ & 1,142 & Good \\
\hline TLI & $\leq 2,00$ & 0,914 & Good \\
\hline CFI & $\geq 0,9$ & 0,926 & Good \\
\hline
\end{tabular}

$248.865=$

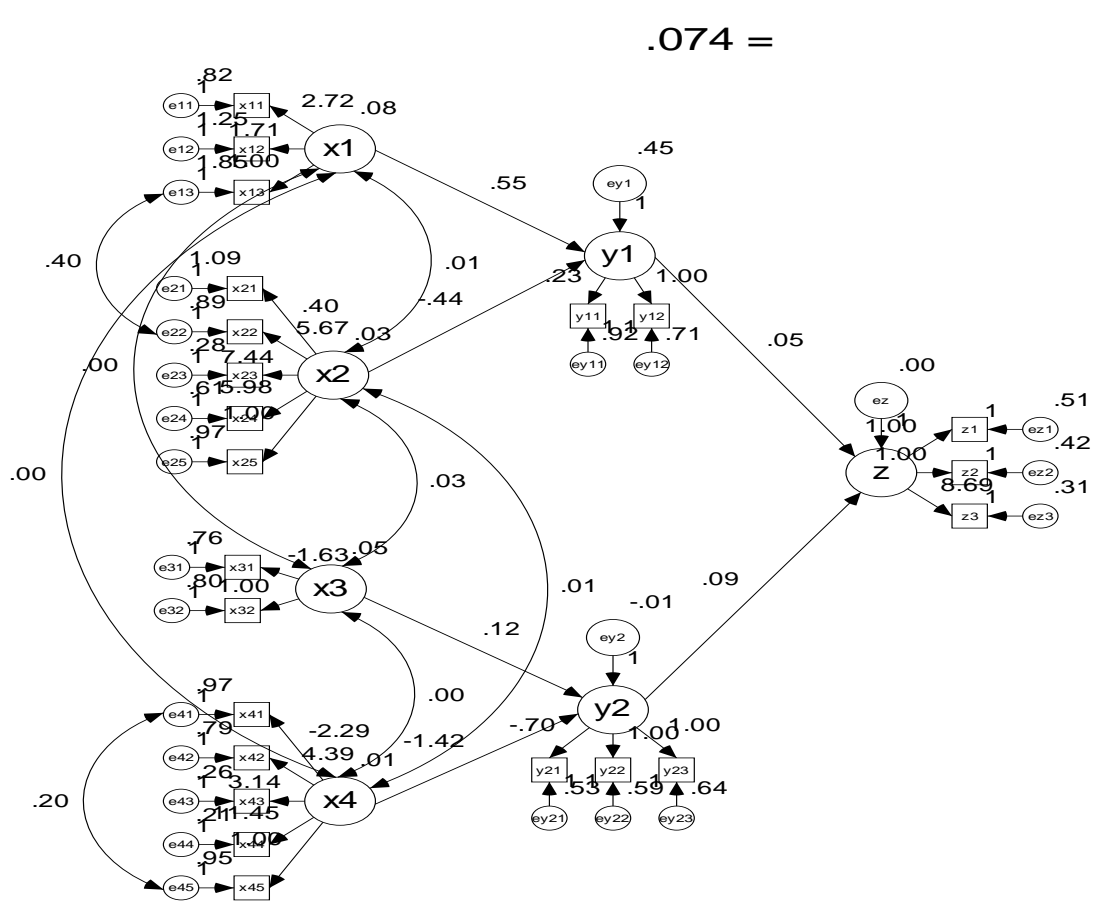

Figure 2. Output of Modification 2. 


\subsection{Regression Weight Analysis}

Other than to test whether a model fitted or not, AMOS program can also analyse the regression weight of one variable to another. An evaluation of the value of regression weight of each variable is: the technology variable does not significantly affec the sub-index because the value of t-count $>0.05$. Marketing and information variable does not significantly affect the sub-index because the value of tcount $>0.05$. Product quality variable does not significantly affect market eficiency because the value of t-count $>0.05$. Management and organization variable does not significantly affect market efficiency because the value of t-count $>0.05$. Sub-index variable does not significantly affect SME innovation index because the value of t-count $>0.05$. Market efficiency variable does not significantly affect SME innovation index because the value of $t$-count $>0.05$. The complete evaluation result of regression weight is available in Table 3.

Table 3. Evaluation of regression weight of causality test.

\begin{tabular}{|l|l|l|l|c|c|c|}
\hline \multicolumn{2}{|l|}{ Variable } & Estimate & S.E. & C.R. & P \\
\hline Technology & $\rightarrow$ & Sub Index & 0,545 & 0,704 & 0,775 & 0,438 \\
\hline $\begin{array}{l}\text { Marketing \& } \\
\text { Information }\end{array}$ & $\rightarrow$ & Sub Index & $-0,437$ & 0,533 & $-0,819$ & 0,413 \\
\hline $\begin{array}{l}\text { Product } \\
\text { Quality }\end{array}$ & $\rightarrow$ & Market Efficiency & 0,124 & 0,266 & 0,463 & 0,643 \\
\hline $\begin{array}{l}\text { Management } \\
\text { \& } \\
\text { Organization }\end{array}$ & $\rightarrow$ & Market Efficiency & $-1,417$ & 1,376 & $-1,030$ & 0,303 \\
\hline Sub Index & $\rightarrow$ & SME Innovation Index & 0,047 & 0,100 & 0,475 & 0,635 \\
\hline $\begin{array}{l}\text { Market } \\
\text { Efficiency }\end{array}$ & $\rightarrow$ & SME Innovation Index & 0,088 & 0,164 & 0,536 & 0,592 \\
\hline
\end{tabular}

\subsection{Direct Effect and Total Effect Analysis}

The size of direct effect of each latent variable (standardized direct effect) and the total effect (standardized total effect) are as follow : technology variable has a direct effect of 0.222 to the subindex. Marketing and information variable has a direct effect of -0.115 to the sub-index. Product quality variable has a direct effect of 0.253 to market efficiency. Management and organization variable has a direct effect of -1.230 to market efficiency. Sub-index variable has a direct effect of 0.675 to SME innovation index. Market efficiency variable has a direct effect of -0.195 to SME innovation index. A summary of the result is available in Table 4.

Table 4. Direct Effect and Total Effect.

\begin{tabular}{|l|l|l|}
\hline Variable & Direct Effect & Total Effect \\
\hline Technology $\rightarrow$ Sub index & 0,222 & 0,222 \\
\hline Marketing \& Information $\rightarrow$ Sub index & $-0,115$ & $-0,115$ \\
\hline Product Quality $\rightarrow$ Market Efficiency & 0,253 & 0,253 \\
\hline $\begin{array}{l}\text { Management \& Organization } \rightarrow \text { Market } \\
\text { Efficiency }\end{array}$ & $-1,230$ & $-1,230$ \\
\hline Sub index $\rightarrow$ SME Innovation Index & 0,675 & 0,675 \\
\hline Market Efficiency $\rightarrow$ SME Innovation Index & 0,195 & 0,195 \\
\hline
\end{tabular}




\subsection{Coefficient Determinant Analysis}

The contribution of each variable simultaneously to other variable is as follow: Technology variable and marketing and information variable have an impact of 5.3\% to strategy sub-index. Product quality variable and management \& organization variable have an impact of $149.8 \%$ to market efficiency. If it is normalized, it is found that product quality variable and organization management variable have the highest impact, that is $96 \%$, while technology and marketing and information have an impact of $4 \%$. Sub-index variable and market efficiency have an impact of $49.4 \%$ the SME innovation index. The result of coefficient determinant is available in Table 5.

Table 5. Coefficient Determinant.

\begin{tabular}{|l|l|l|}
\hline Independent Variable & Dependent Variable & Effective Contribution \\
\hline Technology & Sub index & $4 \%$ \\
\hline Marketing \& Information & Market Efficiency & $96 \%$ \\
\hline Product Quality & \multirow{2}{*}{ SME Innovation Index } & $49,4 \%$ \\
\hline Management \& Organization & Sub index & Market Efficiency
\end{tabular}

\section{Conclusion}

The results of the analysis concluded that after the conceptual model had been modified, the SMB innovation index could be declared as fitted which means that it is fit with the existing empirical conditions. Thus, the criteria in the SME Innovation Index Model can be used to classify the innovation quality of the SMB being assessed.

Nevertheless, the variables constructed in the model are concluded not to have significant impact to other variables because the utilized data input was not a result of real respondent survey designated by the constructed questionnaire.

\section{References}

1. Adiningsih S. Regulasi dalam revitalisasi UKM di Indonesia [Internet]. 2007. Available from: http://www.lfip.org/english/pdf/bali-seminar/Regulasi dalam revitalisasi - sri adiningsih.pdf

2. Great Britain. Department for Culture M and SCITF. Creative industries : mapping document. London: Creative Industries, Department for Culture, Media and Sport; 2001.

3. Tan BS. The Consequences of Innovation. Innov J Public Sect Innov J. 2004;9(3).

4. Baregheh A, Rowley J, Sambrook S. Towards a multidisciplinary definition of innovation. Manag Decis. 2009 Sep 4;47(8):1323-39.

5. Vacek J, Skalický J, S̆lechtová Y, Horák J. U-SME Innovation: Design of a model for joint university-SME Innovation. 2002.

6. Rosid A. Manajemen Usaha Kecil Menengah Koperasi. Pusat Pengembangan Bahan Ajar UMB; 2008.

7. Schwab K, World Economic Forum. The Global Competitiveness Report. Geneva; 2009.

8. Domb E, King B, Tate K. Systematic innovation: a new method for resolving design and manufacturing problems in new product development. PM Netw. 1996;10(3):42-3. 